日臨外会誌 $63(10), 2374-2380,2002$

原 著

治癒切除例の予後からみた80歳以上高齢者胃癌手術の検討

\begin{tabular}{llllllllllll}
\multicolumn{10}{c}{ 栃木県立がんセンター外科 } \\
唐 & 崎 & 秀 & 則 & 稲 & 田 & 高 & 男 & 宮 & 田 & 博 & 志 \\
石 & 原 & 雅 & 巳 & 富 & 川 & 盛 & 啓 & 尾 & 澤 & & 巌 \\
菱 & 沼 & 正 & 一 & 清 & 水 & 秀 & 昭 & 固 & 武 & 健二郎
\end{tabular}

高齢者胃癌治療では，根治性の追求とともに合併症や早期他病死を避けるための侵䒾 の軽減が求められる. 今回われわれは治痹切除術が施行された 80 歳以上の高龄者胃癌 49 症例を対象として術後予後因子の検討を行った. 手術後 5 年以内の死亡は原病死 6 例, 他病死10例の計16例であった．原病死例では，癌進行度と胃切除範囲が有意な予後要因 であったが，リンパ節郭清度の影響は㸾められなかった。他病死例に扝いては，進行度 と術後合併症の有無が有意であり, 術後合併症の発症は術中出血量との相関が認められ たが, 術前諸因子から術後合併症の発症を予測すること蛙困難と考光られた。 以上より， 進行度が原病死，他病死の双方に影響を有する一方で，リンパ節郭清度の影蠁は認めら れず, 術中出血量が術後合併症の発症に影響を与えていることから, 高路者胃癌外科治 療では必要最小限の切除が望ましいものと考えられた。

索引用語：高齢者胃癌，予後因子，術後合併症

\section{緒言}

近年, 胃癌全体の惟患率は減少を続けているものの， 平均寿命の延長とともに，日常診療において，高齢者 の胃癌症例に遭遇する機会は増大している1．一般的 に，胃癌治療において，予後の向上のためには，病変 の早期発見と根治性の確保が重要である。しかしなが ら高齢者においては，加齢に伴う全身諸蔵器機能の低 下の影響など，その特殊性を踏まえ，根治性と侵襲軽 減のバランスを考慮した外科治療を行うことが必要で あるとされる。

今回，われわれは高齢者胃癌治癒切除症例を対象と し，術後生存期間に影響する予後因子を解析すること から，高齢者胃癌の特性とさらに予後を改善するため にはどのような治療方針を選択すべきかについて検討 した。

対象と方法

\section{1. 対象}

検討対象は，1987年から2000年12月までの14年間に

2002 年 2 月25日受付 2002 年 6 月19日採用

〈所属施設住所〉

干320-0834 宇都宮市陽南 $4-9-13$
当院で治癒切除が施行された胃癌症例の内, 手術時 80 歳以上であった54症例中，他癌を合併していた 2 例と 死因の不明であった 3 例を除く49例である．対象症例 の平均年閝は $82.0 \pm 2.08$ 歳であり，最高齢は87歳であ った。

2. 方法

1 ）術前合併基礎疾患の検討

術前評価としては，心，肺，肝，腎機能，耐糖能異 常の有無, 筫血の有無, 栄養状態の 7 項目を検討した

（表 1)。また栄責状態の指標としては，小野寺らの 予後推定栄養指数 (prognostic nutritional index; $\mathrm{PNI}=10 \mathrm{Alb}+0.005 \mathrm{Lymph}$ count）を用いた。

2 ) 予後因子の検討

予後因子の検討に取り上げた項目は, 胃癌進行度, 術前基礎疾患数，胃切除簌囲，リンパ節郭清度，術後 合併症の有無, 術中出血量の 6 因子であり，これらの 因子, それぞれが術後生存期間に与える影響を Coxの 比例ハザードモデルを用いて検討した．術後観察期間 は 5 年間とし，死亡原因の検討は，本センターに放い て再発死亡が確認されている症例および電話調査など により行った。

3 ）術後合併症の検討 
表 1 術前合併基礎疾患

\begin{tabular}{|c|c|c|c|}
\hline 項目 & 異常基準 & 異常症例数 & ()$: \%$ \\
\hline 心機能 & 心霆図買常 (不整脈, ST変化, 脚ブロック) & 18 & $(36.7)$ \\
\hline 肺機能 & $\begin{array}{l}\text { \%VC 80\%未满, FEV1.0 70\%未淽 } \\
\mathrm{PaO} 2<70 \mathrm{mmHg}, \mathrm{PaCO}>45 \mathrm{mmHg}\end{array}$ & 33 & $(67.3)$ \\
\hline 肝機能 & $\begin{array}{l}\text { GOT GPT }>50 \mathrm{IU} / 1 \\
\mathrm{~T}-\mathrm{Bil}>1.0 \mathrm{mg} / \mathrm{dl}, \quad \mathrm{ChE}<150 \mathrm{IU} / \mathrm{l}\end{array}$ & 6 & $(12.2)$ \\
\hline 軗機能 & $\begin{array}{l}\mathrm{BUN}>25 \mathrm{mg} / \mathrm{dl}, \mathrm{Cr}>1.5 \mathrm{mg} / \mathrm{dl} \\
\text { Creatinine crearance }<50 \mathrm{ml} / \mathrm{min}\end{array}$ & 8 & $(16.3)$ \\
\hline 耐梼能 & Fasting blood sugar $\geqq 120 \mathrm{mg} / \mathrm{dl}$ & 4 & $(8.2)$ \\
\hline 䆩血 & $\mathrm{Hb}<10 \mathrm{~g} / \mathrm{dl}, \mathrm{Ht}<30 \%$ & 11 & $(22.4)$ \\
\hline 低栄盖 & PNI $(10 \mathrm{Alb}+0.005$ Lymph count $)<40$ & 4 & $(8.2)$ \\
\hline
\end{tabular}

表 2 術前合併基礎疾患数

\begin{tabular}{ccc}
\hline 検查值異常項目数 & 症例数 & $($ ) :\% \\
\hline 4 & 3 & $(6.1)$ \\
3 & 7 & $(14.3)$ \\
2 & 18 & $(36.7)$ \\
1 & 15 & $(30.6)$ \\
0 & 6 & $(12.2)$ \\
\hline
\end{tabular}

術後合併症の発症と術前合併基礎疾患，手術的因子 との関連を検討した。

各症例の臨床病理学的因子の分類は, 胃癌取扱い規 約第 13 版 $^{3)}$ に従い, 統計学的解析は, $\operatorname{Cox}$ の比例ハザー ドモデルの他, Mann-Whitney のU test および力イ 2 莱検定を用いた。生存期間の検討は Kaplan-Meier 法にて行い，有意性の検討は logrank-testを用いた。 $\mathrm{p}<0.05$ をって有意差ありと判定した。また数值は 平均値士標準偏差で表した。

\section{結 果}

\section{1. 術前合併基礎疾患の検討}

心, 肺, 肝, 腎機能, 而糖能, 賓血, PNI index の 検査值異常の基準は，表 1 の様に分類した. 7 項目中， 肺機能障害が33症例 $(67.3 \%)$ ともっとも多く，心機 能異常18例 (36.7\%)，負血の合併11例 (22.4\%) がそ れに次いでいた。それぞれの症例における術前合併基 礎疾患数では49例中43例 $(87.8 \%)$ において，なんら かの術前検查異常を有しており，最多で 4 項目，全症 例における中央值は 2 であった（表 2 ）。

\section{2. 予後因子の検討}

術後 5 年間とした観察期間内の死亡症例は16例であ り, 原病死 6 例 $(37.5 \%)$, 他病死10例 $(62.5 \%)$ と他 病死が全体の約 6 割を占めていた。原病死例の平均術 後生存期間1.1土0.68年と他病死例の平均術後生存期

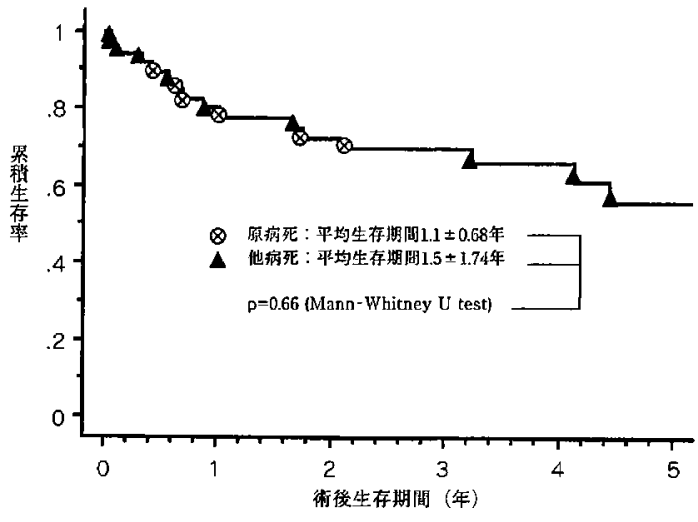

図 1 高齢者胃癌治癒切除術後累積生存率

間1.5土1.74年には有意差は認められなかった（ $\mathrm{p}=$ 0.66 , 図 1 ).

各予後因子と原病死，他病死との間には有意差は認 められなかった（p=0.12，表 3$)$.

全死亡を対象として $\operatorname{Cox} の$ 比例ハザードモデルを もちいて予後因子の検討をすると, 癌進行度 $(p<$ $0.01)$, 胃切除範囲 $(\mathrm{p}=0.03)$ が有意の予後因子であ り, Stage $3 \sim 4$ 症例, 胃全摘例に打いて独立的に予後 不良であった（表 4$)$.また, 術後合併症の有無 $(p=$ 0.07）は有意ではないものの予後に対する影響を有す る傾向にあったが, 術前合併基礎疾患数, リンパ節郭 清度, 術中出血量の多寡は予後に対する影锌は認めら れなかった。

次に原病死のみを対象とし，他病死例を観察打ち切 りとして同樣の検討を行うと, 進行度 $(\mathrm{p}=0.02)$ と切 除範囲 $(\mathrm{p}=0.03)$ が有意であり, Stage $3 \sim 4$ 症例, 全摘例で予後不良であった(表 5 ). また, 術前合併基 礎疾患数 $(\mathrm{p}=0.07)$, 術中出血量の多寡 $(\mathrm{p}=0.07)$ \& 有意ではないものの，予後に対する影響を有する傾向 
表 3 各予後因子と死亡原因

\begin{tabular}{|c|c|c|c|c|}
\hline & & 原病死 ( 6 例) & 他病死 (13例) & $\mathrm{p}$ 值 \\
\hline \multirow[t]{2}{*}{ Stage } & $3 \sim 4$ & 4 & 6 & \\
\hline & $1 \sim 2$ & 2 & 4 & $>0.99$ \\
\hline \multirow[t]{2}{*}{ 術前合併基碟疾㭧数 } & $2 \leqq$ & 3 & 6 & \\
\hline & $2>$ & 3 & 4 & $>0.99$ \\
\hline \multirow[t]{2}{*}{ 切除䇿团 } & 部分切除 & 1 & 7 & \\
\hline & 全摍 & 5 & 3 & 0.12 \\
\hline \multirow[t]{2}{*}{ リンパ節郭清度 } & $\mathrm{D} 2$ & 2 & 4 & \\
\hline & $\mathrm{D} 0 \sim 1$ & 4 & 6 & $>0.99$ \\
\hline \multirow[t]{2}{*}{ 術後合併症 } & 無し & 5 & 5 & \\
\hline & 有り & 1 & 5 & 0.31 \\
\hline \multirow[t]{2}{*}{ 術中出血量 } & $400 \mathrm{ml}>$ & 3 & 7 & \\
\hline & $400 \mathrm{ml} \leqq$ & 3 & 3 & 0.61 \\
\hline
\end{tabular}

表 4 多变量解析による予後因子の検討

\begin{tabular}{|c|c|c|c|c|c|}
\hline & & カイ2乗值 & ハザード比 & 95\%信頼区間 & p値 \\
\hline \multirow[t]{2}{*}{ Stage } & $3 \sim 4$ & & & & \\
\hline & $1 \sim 2$ & 8.07 & 0.13 & $0.03 \sim 0.54$ & $<0.01$ \\
\hline \multirow[t]{2}{*}{ 術前合併基礎疾患数 } & $2 \leqq$ & & & & \\
\hline & $2>$ & 1.27 & 2.51 & $0.51 \sim 12.51$ & 0.26 \\
\hline \multirow[t]{2}{*}{ 切除範囲 } & 部分切除 & & & & \\
\hline & 全摘 & 4.84 & 4.09 & $1.17 \sim 14.33$ & 0.03 \\
\hline \multirow{2}{*}{ リンパ節郭清度 } & $\mathrm{D} 2$ & & & & \\
\hline & $\mathrm{D} 0 \sim 1$ & 1.29 & 0.47 & $0.13 \sim 1.72$ & 0.26 \\
\hline \multirow[t]{2}{*}{ 術後合併症 } & 無し & & & & \\
\hline & 有り & 3.29 & 3.68 & $0.90 \sim 15.08$ & 0.07 \\
\hline \multirow[t]{2}{*}{ 術中出血量 } & $400 \mathrm{ml}>$ & & & & \\
\hline & $400 \mathrm{mI} \leqq$ & 0.81 & 1.99 & $0.44 \sim 8.94$ & 0.37 \\
\hline
\end{tabular}

にあったが, リンパ節郭清度, 術後合併症の有無は予 後に対する影響を認めなかった。

さらに死亡原因の多くを占めていた他病死を対象と して同様の検討をすると，6因子中進行度 $(p=0.048)$ と, 術後合併症の有無 $(p=0.01)$ が有意性を示して扔 り, 一方, 術前合併基礎疾患数, 切除範囲, 術中出血 量の影響は認められなかった(表 6 )。リンパ節郭清度 も予後に対する有意な影響は認められなかったが, D2 郭清後の死亡例峙術後 2 年以内に集中していた（図 2). 他病死の死因洨, 消化管出血, 腹腔内出血による 在院死 2 例, 呼吸不全 3 例, 心不全 2 例, 脳梗塞, 腹 膜炎, 大動脈瘤破裂が各 1 例であった。他病死例 10 例 中，死因と関連がある術前合併基礎疾患または既往疾 患が 3 例で認められたが，術前合併基整疾患と死因に は有意な相関は認められなかった。

\section{3 . 術後合併症の検討}

他病死例の予後に有意な影響を与えていた術後合併
症の発症と他の諸因子との関連を検討すると，有意な 相関を示していたのは術中出血量のみであり（p< 0.01）, 術前合併基礎疾患数を含め, 他因子の影響は認 められなかった(表 7)。

\section{考 察}

平均余命の延長に伴い, 高齢化が進み, 消化器外科 においても，80歳以上の高齢者に対する診療の機会が 増加している。このことから胃癌外科治㙩においても 高齢者に対する至適術式の検討がなされてきた。今ま での報告においては，高齢者であっても予後に影響を 与えるのは癌進行度であり, 慎重な術式の遂行と術前 術後管理により予後の延長が期待できるとし, 積極的 な根治手術を推奨するもの゙) と, 高齢者特有の術前併 存疾患惟患率の高さや，各種臓器機能の低下，また少 後合併症発生率の高さや，他病死の多さから，侵襲の 低い術式を勧めるもの ${ }^{5) ~ 8)}$ に大別される.今回，われわ れは, 当センターに扔ける現在までの自験例の検討か 
表 5 多变量解析による原病死予後因子の検討

\begin{tabular}{|c|c|c|c|c|c|}
\hline & & カイ2采值 & ハザード比 & 95\%信頼区間 & $\mathrm{p}$ 値 \\
\hline \multirow[t]{2}{*}{ Stage } & $3 \sim 4$ & & & & \\
\hline & $1 \sim 2$ & 5.3 & 0.02 & $0.001 \sim 0.57$ & 0.02 \\
\hline \multirow[t]{2}{*}{ 術前合併基磼疾患数 } & $2 \leqq$ & & & & \\
\hline & $2>$ & 3.26 & 49.12 & $0.72 \sim 3,356.13$ & 0.07 \\
\hline \multirow[t]{2}{*}{ 切除篩囲 } & 部分切除 & & & & \\
\hline & 全摘 & 4.54 & 15.47 & $1.24 \sim 192.36$ & 0.03 \\
\hline \multirow[t]{2}{*}{ リンパ節郭清度 } & $\mathrm{D} 2$ & & & & \\
\hline & $\mathrm{D} 0 \sim 1$ & 0.08 & 0.68 & $0.04 \sim 11.19$ & 0.78 \\
\hline \multirow[t]{2}{*}{ 術後合併症 } & 無し & & & & \\
\hline & 有り & 0.58 & 0.30 & $0.01 \sim 6.64$ & 0.45 \\
\hline \multirow[t]{2}{*}{ 術中出血量 } & $400 \mathrm{ml}>$ & & & & \\
\hline & $400 \mathrm{ml} \leqq$ & 3.35 & 61.57 & $0.75 \sim 5,069.44$ & 0.07 \\
\hline
\end{tabular}

表 6 多変量解析による他病死予後因子の検討

\begin{tabular}{|c|c|c|c|c|c|}
\hline & & カイ2乗值 & ハザード比 & 95\%信頼区間 & p值 \\
\hline \multirow[t]{2}{*}{ Stage } & $3 \sim 4$ & & & & \\
\hline & $1 \sim 2$ & 3.90 & 0.15 & $0.02 \sim 0.99$ & 0.048 \\
\hline \multirow[t]{2}{*}{ 術前合併基礎疾患数 } & $2 \leqq$ & & & & \\
\hline & $2>$ & 0.17 & 1.57 & $0.19 \sim 13.14$ & 0.68 \\
\hline \multirow[t]{2}{*}{ 切除簌囲 } & 部分切除 & & & & \\
\hline & 全摘 & 0.31 & 1.74 & $0.25 \sim 12.17$ & 0.58 \\
\hline \multirow[t]{2}{*}{ リンパ節郭清度 } & D2 & & & & \\
\hline & $\mathrm{D} 0 \sim \mathrm{I}$ & 1.84 & 0.34 & $0.07 \sim 1.62$ & 0.17 \\
\hline \multirow[t]{2}{*}{ 術後合併症 } & 無し & & & & \\
\hline & 有り & 5.94 & 9.38 & $1.55 \sim 56.83$ & 0.01 \\
\hline \multirow[t]{2}{*}{ 術中出血量 } & $400 \mathrm{ml}>$ & & & & \\
\hline & $400 \mathrm{ml} \leqq$ & 0.01 & 0.93 & $0.17 \sim 5.23$ & 0.94 \\
\hline
\end{tabular}

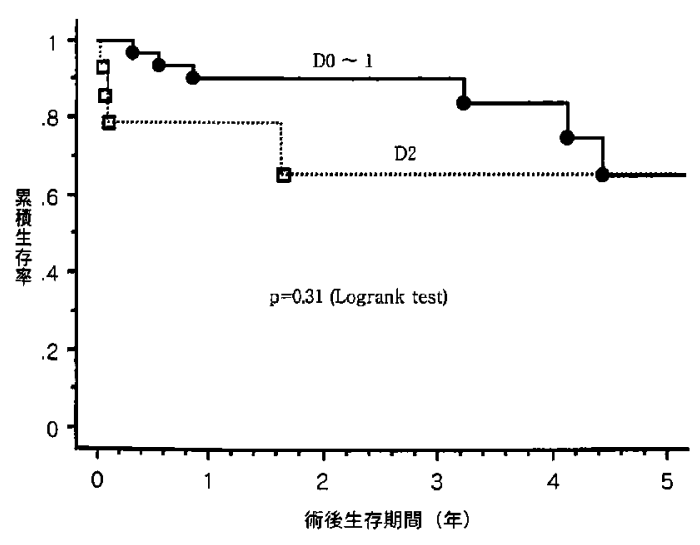

図 2 他病死症例リンパ節郭清度別術後累積生存率

ら，高龄者胃癌症例における適切な外科治療を検証し てみた。

高齢者胃癌では，死亡原因として，他病死の占める
割合が多いとされ(4)-699, 今回の検討でも, 原病死 6 例 (37.5\%)，他病死10例 (62.5\%) と他病死が死亡原因 の多くを占めていた。一般的に高唃者胃癌の術後生存 率は若年者に比し不良とされるが, 年噛を考慮した相 対生存率では差がないとする報告もみられいれ，他病 死例の予後要因の検討は高齖者胃癌の特徵を理解し, 治療方針を決定する上で有用と考えられる。すなわち 術前の合併基礎疾患の有無, 程度や胃癌の進行度によ り，症例ごとに他病死，原病死のいずれが high risk で あることが予測されるかによって, 手術術式の選択を 行うこともありうる.そこで, 今回われわ扎は原病死 と他病死，それぞれの予後因子を別個に検討してみた。 全死亡を対象とした予後因子の検討では, 進行度と 切除範囲の 2 要因が有意の予後因子であった，胃全摘 では若年者に比し, 高龄者で術後合併症の発生率や死 亡率が高いとする報告がみられる一方で9, 長期生存 率に関しては若年者と有意差なしとする報告もあ 
表 7 術後合併症危険因子

\begin{tabular}{|c|c|c|c|c|}
\hline & & \multicolumn{2}{|c|}{ 術後合併症 } & \multirow[b]{2}{*}{$\mathrm{p}$ 值 } \\
\hline & & 有り & 無し & \\
\hline \multirow[t]{2}{*}{ Stage } & $3 \sim 4$ & 5 & 9 & \\
\hline & $1 \sim 2$ & 5 & 30 & 0.12 \\
\hline \multirow[t]{2}{*}{ 術前合併基礎疾患数 } & $2 \leqq$ & 5 & 14 & \\
\hline & $2>$ & 5 & 25 & 0.48 \\
\hline \multirow[t]{2}{*}{ 胃切除範囲 } & 部分切除 & 7 & 29 & \\
\hline & 全摘 & 3 & 10 & $>0.99$ \\
\hline \multirow[t]{2}{*}{ リンパ飾郭清度 } & D2 & 4 & 10 & \\
\hline & $\mathrm{D} 0 \sim 1$ & 6 & 29 & 0.44 \\
\hline \multirow[t]{2}{*}{ 術中出血量 } & $400 \mathrm{ml}>$ & 1 & 33 & \\
\hline & $400 \mathrm{ml} \leqq$ & 9 & 6 & $<0.01$ \\
\hline \multirow[t]{2}{*}{ 他葴器合併切除 } & 有り & 3 & 5 & \\
\hline & 無し & 7 & 34 & 0.33 \\
\hline
\end{tabular}

る ${ }^{11}$. 今回の検討では, 胃全摘例で予後が有意に不良で あったが，死亡原因別の検討では原病死において有意 差を認めるものの，他病死では有意な影響は認められ なかった. 切除範囲と術後合併症の発生の有無, リン 八゚節郭清度, 術中出血量には有意な相関が認められず, 一方で進行度がもう一つの予後因子であることから， 胃全摘の予後不良への関与は侵襲性ではなく, 癌の進 行・進展が反映されている可能性が考えられた。また リンパ節郭清度の関与に関して, 従来の報告では, こ れを高齢者胃癌の有意の予後因子とするものがあり， 高齢者に対しても積極的に根治性を追求すべきとする 論拠となっているが，その多くでは，検討対象に非治 㴰切除例が含まれると同時伅, 積極的な根治術の対象 を術前合併疾患の少ない全身状態良好例に限定してい る ${ }^{4100}$. 今回の検討対象は治癒切除例であり，原病死例 が 6 例と少ないことから，なお多数例での検討を要す るものの, 高齢者胃癌の原病死に対する郭清度の影響 は明らかではなかった。

他病死に与える因子の検討では，進行度と術後合併 症の有無が有意の予後因子であり, リンパ節郭清度, 術前合併基礎疾患の有無を含め, 他因子の影響は認め られなかった。

術後合併症に関してはこれを有意の予後因子とする 報告がある一方で，有意の予後因子ではなかったとす る報告もみられる ${ }^{22)}$. 今回の研究では対象を治痛切除 症例とし，他病死に関する予後因子として検討したこ とから, 術後合併症の有無が有意の予後因子として明 らかになったと考えられる。高齢者には術後合併症の 発生が多く，これが死亡原因の多くを占める他病死の
有意の予後因子となる以上，術後合併症の発生を術前 に予測することは，症例の選択，また合併症の予防の 上で重要である。術後合併症の発生に影響を与える因 子としては, 手術時間6), 術中出血量4)12\}. 術前栄養状 態13などが報告されているが，術前合併基礎疾患の有 無に関しては影響を与えていたとする報告 ${ }^{14)}$ と，影響 がみられなかったとする報告67りに分かれている. 今回 の検討では, 術中出血量のみで有意差を認め, 術前合 併基礎疾患は，その項目数でも，各項目毎に比較して も有意な影響は認められなかった。これは本研究も含 め，予後因子や合併症発生因子に関する検討は retrospective study が多く,このため症例が選択されてい たり，術前に合併基礎疾患を有する症例に対しては， 術後合併症を防ぐための配虑がなされた結果とも考え られるが，同時に術後合併症の発生を術前に推測する ことの困難性を示す結果とも考えられる。また，他病 死例の死因と術前合併基礎疾患との間にも関連は認め られず，他病死に関して今回の結果からは，術前因子 ではその死亡形式も，合併症の発生に関しても推測す ることは困難であった．今回の検討対象には消化管极 よび腹腔内出血により術後30日以内に死亡した在院死 した2例が含まれているが，これらを除いた検討でも 同様の結果であった。したがって術後合併症の発生は, 中長期的にも高齢者胃癌術後他病死に影響を与えると 考えられた。また，他病死例において，リンパ節郭清 度の予後に対する有意な影響は認められないものの， D2 後の死亡時期は術後 2 年以内に集中しておう, 術後 早期他病死への影響が考えられた．したがって高齢者 胃癌外科切除における D2 リンパ節郭清は慎重な適応 
選択を要すると考えられた。

以上より，高龄者胃癌において，進行度が原病死と 他病死の双方に影響を与えている一方で, リンパ節郭 清度は D2 が D0〜 1 と比し原病死例の予後に寄与し ておらず，他病死例では術後早期死亡への関与が考元 られること, また術後死亡原因の多くを占める他病死 において, 術後合併症の有無が重要であり, その発症 が術前の risk factor かららは予測が困難で,ざらに術中 出血量が術後合併症発生に影響を与えていることか ら，現状では高秢者胃癌治療に执いては侵襲の低い， 必要最小限の切除が望ましいと考えられた。

\section{結 語}

過去14年間に経験した80歳以上の高齢者胃癌治癒切 除例を対象とした多変量解析により, 進行度, 胃切除 範囲が予後因子として同定された。進行度は原病死, 他病死の双方に影響を与えていたが, 郭清度の予後改 善への寄与は認められなかった。また, 術後合併症の 有無は死亡原因の多くを占める他病死に影響を与えて 抢り，この発生に術中出血量の多宾の関与が認められ たものの,術前因子から予測することは困難であった。

これらの結果より，現状の高齢者胃癌治療に扔いては 侵襲の低い，必要最小限の切除が望ましいと考えられ た.

\section{文献}

1）估 信博, 沢井清司, 高橋佾雄他：最近 15 年間に おける高齢者胃癌手術症例の臨床病理学的推移。 日消外会誌 $23 ： 851-856,1990$

2）小野寺時夫, 五関諢秀, 神崎五郎他: Stage IV, V ( $\mathrm{V}$ は大腸癌) 消化器癌の非治癒切除の姑息手術 に対するTPN の適応と限界。日外会誌 85 ： 1001-1005, 1984

3）胃癌研究会編：胃癌取扱い規約。第13版，金原出 版, 東京, 1999

4）高金明典, 寺島雅典, 米沢仁志他：多変量解析を 用いた高舲者胃癌症例の術後合併症危隃因子及び 予後因子の検討。日消外会誌 $32 ： 1152-1159$ ， 1999
5）渡辺明彦, 山田 貴, 澤田秀智他：手術成績から みた 80 歳以上高嘢者胃癌切除術式の検討。日消外 会誌 $26: 2287-2292,1993$

6）下松谷匠, 堀内哲也, 吉田 誠他：80歳以上高齢 者胃癌症例の臨床成績と手術術式の選択一 60 歳代 手術症例との比較一. 日臨外会誌 $60: 2305-$ 2310,1999

7) 庄 雅之, 今川敦史, 細井孝純他：高齢者胃癌(80 歲以上) 手術症例の检討. 日臨外会誌 $57: 1838$ -1843, 1996

8）田中邦哉, 鬼頭文彦, 金村栄秀他：高齢者胃癌㧈 よび入腸癌手術の臨床的検討。日臨外会誌 59 ： 42-51, 1998

9) Tsujitani $S$, Katano K,Oka A, et al : Limited operation for gastric cancer in the elderly. $\mathrm{Br}$ J Surg $83:$ :836-839, 1996

10) Katai $H$, Sasako $M$, Sano $T$, et al: The outcome of surgical treatment for gastric carcinoma in the elderly. Jpn J Clin Oncol $28: 112$ $-115,1998$

11) Bittner $R$, Butters $M$, Ulrich $M$, et al: Total gastrectomy. Update operative mortality and long-term survival with particular reference to patients older than 70 years of age. Ann Surg $224: 37-42,1996$

12) Schwarz RE, Karpeh MS, Brennan MF, et al: Factors predicting hospitalization after operative treatment for gastric carcinoma in patients older than 70 years. J Am Coll Surg $184: 9-15,1997$

13）中村光彦, 碓井貞仁, 長尾二郎他：高齢者腹部外 科手術の問題点とその対策。日臨外会誌 58 ： 2246-2253, 1997

14) Roviello F, Marrelli D, De Stefano A, et al: Complications after surgery for gastric cancer in patients aged 80 years and over. Jpn J Clin Oncol 28:116-122, 1998 


\title{
PROGNOSTIC FACTORS OF CURATIVELY RESECTED GASTRIC CANCER IN PATIENTS AGED 80 YEARS AND OLDER
}

\author{
Hidenori KARASAKI, Takao INADA, Hiroshi MIYATA, \\ Masami ISHIHARA, Moriaki TOMIKAWA, Iwao OZAWA, \\ Shoichi HISHINUMA, Hideaki SHIMIZU and Kenjiro KOTAKE \\ Department of Surgery, Tochigi Cancer Center
}

In the treatment of aged patients with gastric cancer, the curative intent is required but minimally invasiveness is also important to avoid postoperative complications and early death due to other diseases. This study aimed at analysing prognostic factors in 52 aged patients (80 years and older) with gastric cancer who underwent a curative gastrectomy. Six patients died of gastric cancer, and 13 of other diseases during 5 postoperative years. In cases of cancer death, pathological stage and the extent of gastrectomy were identified as significant prognostic factors. The extent of lymph node dissection had no influence on the prognosis. As for the death due to other disease, pathological stage and the occurrence of postoperative complications were identified as significant prognostic factors. The occurrence of postoperative complications was significantly correlated with the amount of intraoperative bleeding, and not correlated with other factors including preoperative risk factors. From these results, it is assumed that the minimal invasive surgery should be recommended for elderly patients with gastric cancer. 